\title{
BALIKA fact sheet: Highlight on married adolescents
}

Population Council

Follow this and additional works at: https://knowledgecommons.popcouncil.org/departments_sbsr-pgy

Part of the Demography, Population, and Ecology Commons, Family, Life Course, and Society Commons, and the International Public Health Commons How does access to this work benefit you? Let us know!

\section{Recommended Citation}

"BALIKA fact sheet: Highlight on married adolescents." New York: Population Council, 2014. 


\section{Lack of power within the marital relationship can} compromise a girl's ability to exercise her reproductive rights, timing of childbearing, and decisions related to family planning and maternal and child health services.

- In Bangladesh marriage marks the beginning of sanctioned sexual activity as well as increased social isolation, as girls typically leave their homes and natal villages, losing contact with friends and peers.

- Marriage leads to social isolation when marriage marks an end to schooling. When girls are not in school, they miss the opportunity to interact with same-age peers and form social networks. They may be less likely to gain skills and knowledge and ultimately have less earning power.

- Married adolescents have poorer sexual and reproductive health knowledge and more unequal gender attitudes.

- Young girls who are married to men who are much older are in a disadvantaged position to negotiate in their marital home. This can have implications for realizing her sexual and reproductive choice and health rights.

\section{CHILDBEARING STARTS SOON AFTER MARRIAGE}

Among all married adolescents of aged 12-19

\section{$15 \%$ are currently pregnant and}

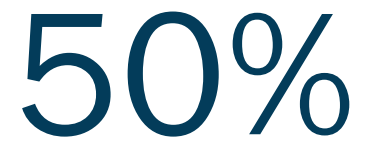

ever conceived

- Among those ever-married, 22\% had a pregnancy by age 15.

- $64 \%$ delivered at home.

\section{HIGHLIGHTS}

- In Bangladesh, early marriage leads to early sexual debut and early pregnancy. Among those who are married, $22 \%$ had a pregnancy by age 15 .

- Typically spousal age difference is large, with husbands 7-8 years older than their wives. Older husbands exercise more authority and have different priorities, which frequently puts married girls at a disadvantage in terms of negotiating the timing and choice of childbearing. Among those who have a child, $64 \%$ delivered at home.

- Knowledge of family planning is high $(99 \%)$ as well as current use of contraception (65\%) among girls. Thus even though childbearing is early it does not preclude fertility control starting at an early age.

- $77 \%$ have heard of HIV but only $36 \%$ have correct knowledge of transmission of HIV.

- Knowledge of other sexually transmitted infections (STI) like syphilis and gonorrhea is dismally low, only $9 \%$.

- In a significant departure from past surveys that found marriage effectively puts an end to schooling, the Balika survey finds that $20 \%$ of married adolescents continue their schooling albeit under considerable constraints posed by their marital roles and responsibilities. 
Rita [fictitious] was married at the age of 7 . Her husband was 22 years old at that time. She menstruated once or twice before she became pregnant with her first child at the age of 12 . Now she does not want another child immediately but finds it difficult to negotiate with her husband:

\section{"My husband wants another child and} forbids me to take the pill. I already have a small child; if I become pregnant again now it will be very difficult for me. So I take the pill, but in secret."

\section{KNOWLEDGE AND PRACTICE OF CONTRACEPTION}

- A high proportion of adolescents reported on their use of contraceptives. The rates are consistent with a high degree of fertility control in the area.

- $85 \%$ have used some kind of contraception in the past and $65 \%$ are currently using contraception.

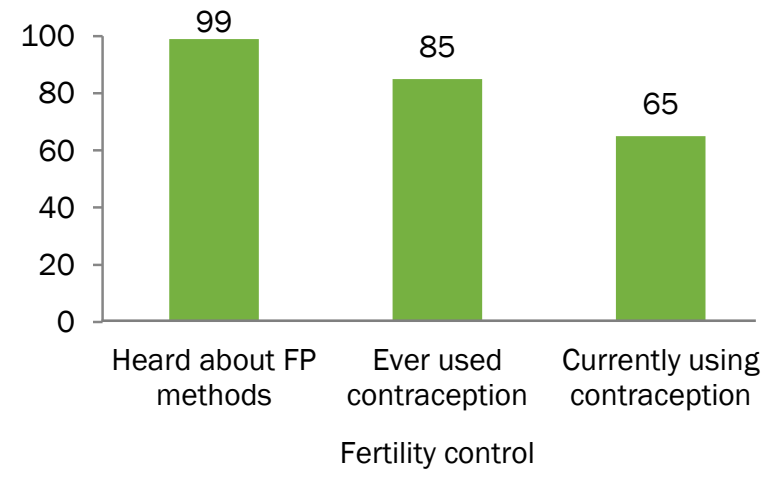

\section{HIV KNOWLEDGE}

$77 \%$ had ever heard about HIV but only $36 \%$ had correct knowledge of transmission

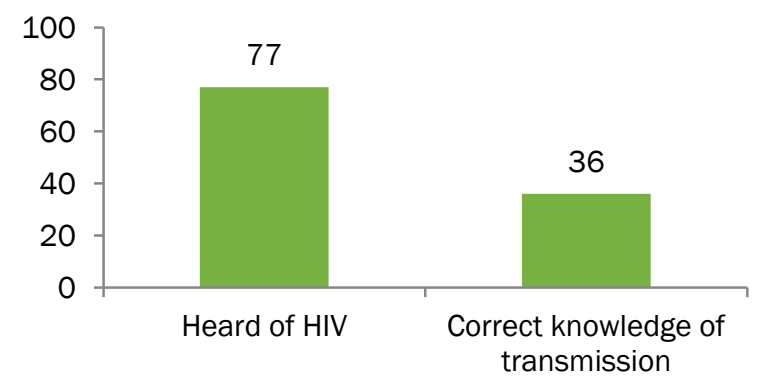

POOR KNOWLEDGE OF SEXUALLY TRANSMITTED INFECTIONS (STI)

Among all married adolescents

$9 \%$

had heard of syphilis/gonorrhea

\section{CONTINUING SCHOOLING}

Among all married adolescents
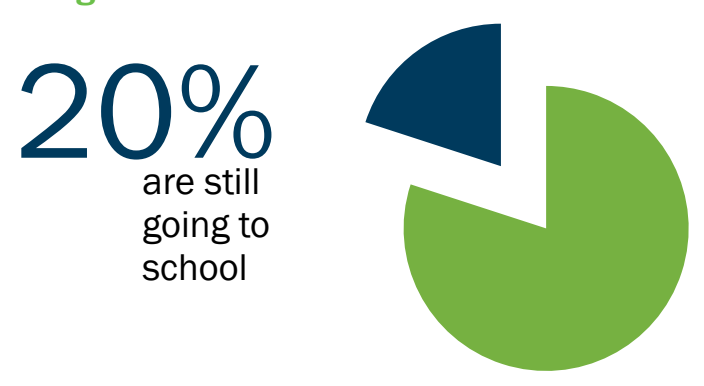

The increase in the percentage of married adolescents continuing their education reveals a remarkable departure from past surveys. However, as the quote below suggests, continuing school entails significant cost:

"I was in the seventh standard at the time of marriage. I kept on studying on the sly. During exam time, I would find excuses to visit my parents, usually for an extended period, and sat for exams at my old school. Sadly ... my in-laws found out about it and stopped me from appearing for the final exam. My father-in-law said "You have to sweep the courtyard no matter if you are educated or not-nothing will change-so why bother studying!" After that incident, my in-laws did not allow me to visit my parents for a year."

-GIRL AGED 19, KHULNA

\section{CONCLUSION}

The most remarkable change is in the high proportion of girls who report continuing schooling. It is possible that while the reality of marriage-related responsibilities precludes any effective time spent in school, girls are motivated to continue being enrolled in school.

From the findings it appears that it is common for most girls to bear a child soon after marriage. As a result, most married adolescents are either currently pregnant or have already had children. A very high proportion of adolescents reported practicing contraception. Rates of contraception are consistent with a high degree of fertility control in the area. Thus early childbearing does not preclude fertility control. Finally, questions asked about fertility control and sexually transmitted diseases show that while knowledge about family planning is high, other types of reproductive health knowledge are verv low. 